\title{
The socio-economics of artisanal mining and bushmeat hunting around protected areas: Kahuzi- Biega National Park and Itombwe Nature Reserve, eastern Democratic Republic of Congo-ERRATUM
}

Charlotte Spira, Andrew Kirkby, Deo Kujirakninja and Andrew J. Plumptre

DOI: 10.1017/S003060531600171X. Published online by Cambridge University Press, 11 April 2017

We regret that an error was introduced in Table 2 in Spira et al. (2017) during the production process. The correct unit for the mean price of gold is USD $\mathrm{g}^{-1}$, not USD kg$^{-1}$. The correct table is presented below.

\section{Reference}

Spira, C., Kirkby, A., Kujirakwinja, D. \& Plumptre, A.J. (2017) The socio-economics of artisanal mining and bushmeat hunting around protected areas: Kahuzi-Biega National Park and Itombwe Nature Reserve, eastern Democratic Republic of Congo. Oryx. Published 11 April 2017, doi: 10.1017/Soo3060531600171X.

TABLE 2 Mean sale price of cassiterite, coltan and gold at various points along the value chain. Blank cells indicate no data.

\begin{tabular}{|c|c|c|c|}
\hline \multirow[b]{2}{*}{ Point of sale } & \multicolumn{3}{|l|}{ Mean price } \\
\hline & $\begin{array}{l}\text { Cassiterite, }\left(\mathrm{USD} \mathrm{kg}^{-1}\right) \\
(\mathrm{n}=589)\end{array}$ & $\begin{array}{l}\text { Coltan, }\left(\mathrm{USD} \mathrm{kg}^{-1}\right) \\
(\mathrm{n}=48)\end{array}$ & $\begin{array}{l}\left.\text { Gold (USD g }{ }^{-1}\right) \\
(\mathrm{n}=227)\end{array}$ \\
\hline Mine site & 2.7 & 19.8 & 34.0 \\
\hline Village trader & 3.3 & 22.6 & 34.5 \\
\hline Large urban centre & 3.0 & & 36.6 \\
\hline Global market value (March 2015)* & 17.4 & 177.8 & 37.4 \\
\hline
\end{tabular}

*InfoMine (2015) 